\title{
ASAS KEBEBASAN BERKONTRAK DALAM PEMBIAYAAN MUDHARABAH PADA PERBANKAN SYARI'AH
}

\author{
Oleh: Ibnu Rusydi, S.H., M.Pd.I., M.H. ${ }^{*}$
}

\begin{abstract}
Freedom to make contracts sometimes becomes a means to know the wishes of the parties and willingness and agreement in between. While at Sayriah Banking freedom of contract is applied to attract as many customers. The standard contract which is juxtaposed with mudharabah contract which notabennya akad which require deliberation, there will be harmonization and injustice. This problem will affect the lives of customers, where customers will feel aggrieved over the contract made unilaterally.
\end{abstract}

Keywords: Mudharabah Financing Agreement, Freedom of Contract.

\section{Abstrak}

Kebebasan membuat kontrak terkadang menjadi suatu sarana untuk mengetahui keinginan para pihak serta kerelaan dan kesepakatan di antara mereka. Sementara di Perbankan Syariah, kebebasan berkontrak diterapkan untuk menarik nasabah sebanyak banyaknya. Kontrak baku yang disandingkan dengan akad mudharabah yang notabennya adalah akad yang memerlukan musyawarah, menyebabkan ketidak selarasan dan ketidak adilan. Problematika ini akan berdampak pada kehidupan nasabah, di mana nasabah akan merasa dirugikan atas kontrak yang dibuat secara sepihak.

Kata Kunci: Pembiayaan Mudharabah, Asas Kebebasan Berkontrak.

\section{Pendahuluan}

Latar belakang kemunculan bank-bank syariah bila diamati dari segi tujuannya, tentu sangat pantas bank syariah menuai pujian dan dukungan sebagai institusi perbankan alternatif bagi umat Islam yang membutuhkan jasa perbankan tanpa dihantui dosa riba dan aktivitas terlarang lainnya, terlebih dalam aneka akad yang dilaksanakan oleh perbankan syariah. Rujukannya adalah Fatwa Dewan Syariah Nasional (selanjutnya disingkat DSN) di mana fatwa DSN pun rujukan penetapan fatwanya adalah dari pendapat ulama, khususnya ulama madzhab Hanafiyah, yang merupakan salah satu madzhab yang diakui kebenarananya dalam ajaran Islam.

Salah satu bidang muamalat yang mengalami perkembangan cepat adalah masalah perjanjian atau kontrak. Penyebab utama pesatnya

\footnotetext{
*) Dosen Tetap Fakultas Hukum Universitas Galuh
} 
perkembangan perjanjian adalah karena adanya asas kebebasan berkontrak, yaitu memberikan kebebasan bagi setiap orang untuk mengadakan perjanjian apapun dan bagaimana jenis dan isinya, baik yang sudah diatur atau belum diatur dalam undang-undang. (Abdul Kadir, 1993: 223).

Dalam asas kebebasan berkontrak, pembuat Undang-undang memberikan asas ini kepada para pihak yang berjanji sekaligus memberikan kekuatan hukum yang mengikat kepada para pihak yang berjanji sekaligus memberikan kekuatan hukum yang mengikat kepada apa yang telah mereka perjanjikan (pacta sunt servanda), seperti yang dimaksud dalam pasal 1338 ayat 1 KUHPerdata yang berbunyi "semua perjanjian yang dibuat secara sah berlaku sebagai Undang-undang bagi mereka yang membuatnya" (Subekti dan Tjitrosudibio, 2004: 342)

Sebagaimana lazimnya dalam pembuatan kontrak, tentunya akan dimulai dengan hal-hal yang bersifat fundamental. Para pihak biasanya akan melakukan pembicaraan satu sama lain. Sebab, jika suatu kontrak tidak didefinisikan secara jelas mengenai sesuatu yang di maksud, bisa akan menimbulkan persoalan-persoalan yang baru. (Subekti dan Tjitrosudibio, 2004: 342).

Asas kebebasan berkontrak apabila dikaitkan dengan permasalahan modern terutama tentang lembaga perbankan (dalam hal ini Perbankan Islam), akan mempunyai implikasi yang sangat besar dikarenakan adanya kebebasan di dalamnya, yaitu setiap orang bebas untuk membuat atau tidak membuat perjanjian-perjanjian baru dengan mengabaikan perjanjian-perjanjian yang telah ada didalam teks-teks hukum Islam atau di dalam Undang-Undang, karena hukum-hukum tersebut pada prinsipnya hanya berfungsi sebagai optional law.

Menurut Munir Fuady, (2001: 30) bahwa pada prinsipnya hukum kontrak tergolong ke dalam hukum mengatur. Artinya adalah bahwa hukum tersebut berlaku sepanjang para pihak tidak mengaturnya, lain jika para pihak dalam kontrak mengatur secara lain dari yang diatur dalam hukum kontrak, maka yang berlaku adalah apa yang diatur sendiri oleh para pihak tersebut, kecuali UndangUndang menentukan lain, meskipun menurut Sutan Remy Sjahdeini (1993: 296) bahwa asas kebebasan berkontrak yang tidak terbatas dapat menimbulkan ketidakadilan apabila para pihak mempunyai kekuatan kedudukan yang tidak seimbang, karena perjanjian-perjanjian yang dihasilkan adalah perjanjian yang 
berat sebelah dan sering mengandung klausul-klausul yang secara tidak wajar memberatkan bagi salah satu pihak.

Asas kebebasan berkontrak juga dianut dalam Hukum Perjanjian Islam. Dalam asas kebebasan berkontrak dimaksudkan kebebasan seseorang untuk membuat perjanjian macam apapun dan berisi apa saja sesuai dengan kepentingannya dalam batas-batas kesusilaan dan ketertiban umum, sekalipun perjanjian itu bertentangan dengan pasal-pasal hukum perjanjian (Subekti, 1996: 13). Hal ini untuk menjaga agar jangan sampai terjadi penganiayaan antara sesama manusia melalui akad dan syarat-syarat yang dibuatnya. Dengan kata lain dapat dinyatakan bahwa dalam hal praktek-praktek bidang kegiatan perbankan secara normal dan tidak bertentangan dengan syariat Islam, Bank Syariah dapat mengadopsi sistem dan prosedur Perbankan yang ada. Dalam hal terjadi pertentangan dengan syariat, maka Bank-Bank Islam merencakan dan menerapkan praktek dan prosedur mereka sendiri, guna menyesuaikan aktivitas Perbankan mereka dengan prinsip-prinsip Syariah Islam.

Jika melihat kepada Lembaga Keuangan Syariah atau Perbankan Syariah dalam melaksanakan pembiayaan, masih belum begitu jelas mengenai mekanisme kebebasan berkontrak dalam pembuatan suatu kontrak (akad). Biasanya kebebasan berkontrak cenderung untuk nasabah yang daya tawarnya tinggi (high bargaining position) saja, sementara nasabah yang mempunyai daya tawar rendah (low bargaining position), pihak Bank cenderung menggunakan kontrak standar yang telah dibuat terlebih dahulu oleh pihak Bank.

Seiring waktu berjalan, saat terjadinya interaksi di antara praktisi perbankan, nasabah dengan para ahli ilmu agama Islam serta kajian-kajian yang mendalam maka sedikit demi sedikit mulai bermunculan temuan berbagai penyimpangan yang terjadi baik pada proses akad muamalah berlaku yang diterapkan oleh bank syariah maupun konsep dasarnya yang melandasi berdirinya perbankan syariah baik dalam produk pendanaan maupun produk pembiayaannya. Dalam konteks diskursus ini, hanya diangkat seputar akad pembiayaan mudharabah yang di terapkan oleh perbankan syariah di Indonesia untuk memberi gambaran dan penegasan mengenai akad pembiayaan mudhrabah yang bersifat baku, benarkah dapat menjamin akad yang adil bagi para pihak serta tentang implementasi asas kebebasan berkontrak pada akad mudharabah yang mewujudkan keadilan. 


\section{Pembahasan}

Kontrak baku telah digunakan secara meluas dalam dunia bisnis sejak lebih dari delapan puluh tahun lamanya. Adanya kontrak baku karena dunia bisnis memang membutuhkannya. Oleh karena itu, lambat laun kontrak baku diterima oleh masyarakat (Ifayah, 2008: 5). Namun di era sekarang ini seluruh lapisan masyarakat Indonesia belum tentu dapat menerima kontrak baku sepenuhnya.

Perjanjian baku dalam praktiknya dapat merugikan pihak yang lebih lemah, sedangkan bila dilihat dari keabsahan berlakunya perjanjian baku dapat dilihat dari syarat-syarat subjektif dan objektif dari pasal 1320 KUHPerdata yaitu kesepakatan, kecakapan, hal tertentu, dan sebab yang halal. Ada dua syarat yang harus dipenuhi nasabah dalam melakukan perjanjian baku. Dua syarat yang pertama dinamakan syarat-syarat subjektif karena mengenai orang-orang atau subjek yang mengadakan perjanjian, sedangkan dua syarat terakhir dinamakan syarat-syarat objektif karena mengenai perjanjiannya sendiri atau objek perbuatan hukum yang dilakukan itu. Apabila syarat objektif tidak terpenuhi, perjanjian itu batal demi hukum (Himawan dkk, 2014: 46).

Perjanjian pembiayaan di perbankan yang bersifat baku (standar contract) senantiasa membebani nasabah dengan berbagai macam kewajiban, termasuk tanggungjawab atas risiko yang ditimbulkan selama perjanjian berlangsung. Kondisi ini menimbulkan tanggungjawab minus di pihak bank dan tanggungjawab tidak terbatas di pihak nasabah (Paska, 2012: 2).

Kontrak baku memang sudah biasa digunakan dalam perjanjian pembiayaan di perbankan konvensional, bahkan juga pada perbankan syariah. Ketika kontrak baku ini disandingkan dengan akad-akad pembiayaan yang berprinsipkan pada syariah yang memerlukan musyawarah dalam pembagian nisbah bagi hasilnya, maka akan didapati ketidak teraturan. Salah satu contohnya saja akad pembiayaan mudharabah (bagi hasil).

Pasal 19 Undang-Undang Nomor. 21 Tahun 2008 tentang Perbankan Syariah, menjelaskan bahwa mudharabah adalah akad kerja sama suatu usaha antara pihak pertama (bank syariah) yang menyediakan seluruh modal dan pihak kedua (nasabah) yang bertindak selaku pengelola dana dengan membagi keuntungan usaha sesuai dengan kesepakatan yang dituangkan dalam akad, 
sedangkan kerugian ditanggung sepenuhnya oleh bank syariah kecuali jika pihak kedua melakukan kesalahan yang disengaja, lalai atau menyalahi perjanjian.

Secara teknis, implementasi akad pembiayaan mudharabah dalam produk perbankan berupa giro, tabungan, dan deposito dapat dibaca di dalam SEBI No. 10/14/DpbS tertanggal 17 Maret 2008, yang merupakan ketentuan pelaksana dari PBI No.9/19/PBI/2007 tentang pelaksanaan prinsip syariah dalam kegiatan penghimpunan dana dan penyaluran dana serta pelayanan jasa bank syariah, sebagaimana yang telah diubah dengan PBI No.10/16/PBI/2008 ( Anshori, 2010: 108).

Dalam akad mudharabah diperlukan adanya kesepakatan nisbah yang tepat di antara bank dengan nasabah. Perjanjian pembiayaan mudharabah dapat juga dilakukan antara beberapa penyedia dana dan pelaku usaha. Jika usaha mengalami kerugian, maka seluruh kerugian ditanggung oleh pemilik dana, kecuali jika ditemukan adanya kelalaian atau kesalahan oleh pengelola dana, seperti penyelewengan, kecurangan, dan penyalahgunaan dana. Keuntungan usaha secara mudharabah dibagi menurut kesepakatan yang dituangkan dalam kontrak, sedangkan apabila rugi ditanggung oleh pemilik modal selama kerugian itu bukan akibat kelalaian si pengelola (Zaenudin, 2014: 72).

Apabila kontrak baku disandingkan dengan akad pembiayaan mudharabah yang notabennya akad yang memerlukan musyawarah, maka akan terjadi ketidak selarasan. Problematika ini akan berdampak pada kehidupan nasabah, di mana nasabah akan merasa dirugikan atas kontrak yang dibuat secara sepihak (contract standart) tersebut. Pada awalnya nasabah ingin mendapat modal untuk usahanya, karena isi kontraknya memberatkan, maka pilihan dari nasabah hanya meninggalkan atau tidak jadi melakukan pembiayaan dengan bank (Husnul Khatimah, 2009: 6). Kalaupun pihak nasabah menerima kontrak kerjasama, bisa dipastikan pihak nasabah tersebut menjalankan dengan penuh tanggung jawab yang besar. Selain itu juga nisbah bagian dari nasabah akan kurang sepadan dengan kontribusi kerjasama yang nasabah berikan.

Perjanjian baku atau standar kontrak yang diterapkan oleh perbankan syari'ah secara langsung atau tidak langsung telah menghilangkan atau membatasi kebebasan berkontrak dari mitra kontraknya tersebut. Pada umumnya, dalam suatu perjanjian syari'ah, posisi para pelaku usaha lebih kuat dan dominan dibandingkan posisi dari mitra kontraknya, yang cenderung dipaksa 
baik secara langsung maupun tidak langsung, sehingga calon nasabah bank syari'ah tidak mempunyai pilihan lain kecuali menandatangani kontrak yang sebenarnya banyak mengandung kelemahan (Sjahdeini, 1999: 45).

Jika diperhatikan mekanisme dalam pemakaian perjanjian standar, perjanjian tersebut oleh pihak kesatu disodorkan kepada pihak kedua untuk dipakai tanpa memiliki hak mengkoreksi. Sehingga pihak kedua hanya bersandar pada ketidaktahuan kecuali mau menerima ketentuan dari kontrak patnernya yang telah dituangkan dalam formulir perjanjian baku tersebut. Akibatnya, artian kesepakatan sebagai syarat suatu perikatan dalam pasal 1320 KUHPerdata telah tiada dalam perjanjian standar ini.

Melihat fakta diatas, tidak bisa dipungkiri bahwa formulir atau aplikasi yang disodorkan oleh pihak Perbankan Syariah kepada calon nasabahnya untuk produk pembiayaan mudhrabah adalah perjanjian baku (standart contract). Klausula baku dalam kontrak pembiayaan mudharabah yang diterapkan Perbankan Syariah, pada umumnya tidak diatur secara tegas dalam ketentuan hukum kontrak di Indonesia. Pasal 1338 ayat 3 BW hanya menyatakan bahwa perjanjian harus dilaksanakan dengan itikad baik (goodwill; good faith) di mana ketentuan ini tidak memberikan akibat yang signifikan untuk dapat membatalkan suatu perjanjian yang telah ditandatangani oleh para pihak yang dalam pasal 1338 ayat 1 secara tegas diakui sebagai Undang-Undang (bahkan berlaku sebagai lex specialis terhadap ketentuan umum) yang berlaku dan mengikat para pihak yang menandatangani kontrak tersebut.

Kemungkinan yang lebih dapat menjaga agar tidak terjadi kesewenangan oleh pihak yang posisinya lebih kuat (willkeeur) terhadap pihak yang posisinya lebih lemah, adalah ketentuan yang diatur dalam pasal 1339 BW yang menyatakan sebagai berikut : "Suatu perjanjian tidak hanya mengikat untuk halhal yang dengan tegas dinyatakan didalamnya, tetapi juga untuk segala sesuatu yang menurut sifat perjanjian, diharuskan oleh kepatutan, kebiasaan, atau undang-undang."

Pasal inipun belum secara tegas dapat melindungi kepentingankepentingan dari pihak yang lemah terhadap klausula-klausula baku yang sering lebih berbentuk klausula eksemsi (exemption clouse). Karena kekuatan dari konsekuensi ditandatanganinya suatu kontrak yang memberikan pengertian berdasarkan hukum kontrak Indonesia bahwa kedua belah pihak telah 
melakukan kewajiban duty to care ataupun duty to read membuat sulit bagi pengadilan untuk menerima adanya langkah-langkah untuk melindungi hak-hak dari pihak yang lemah atas dasar kerugian-kerugian yang muncul dari akibat diberlakukannya klausula limitasi tersebut (Endang, 2010: 27).

Khusus dalam suatu draft kontrak tercetak yang diajukan kepada pihak konsumen atau nasabah dari Perbankan Syariah untuk ditandatangani, di mana sebenarnya sebelum langkah penandatanganan kontrak tersebut, tetap saja undang-undang masih melihat bahwa si konsumen atau nasabah tersebut mempunyai hak dan kewajiban untuk membaca (duty to read) dan memahami bahkan melakukan perubahan terhadap draft kontrak yang tercetak tersebut (duty to care). Walaupun diakui posisi si konsumen atau nasabah ataupun pihak yang lemah tersebut dapat menghindar dari suatu kerugian akibat dari kehadiran klausula baku tersebut adalah apabila klausula baku yang dipaksakan tersebut bertentangan dengan kepentingan publik, kesusilaan ataupun bertentangan dengan undang-undang yang berlaku, yang membuat perjanjian tersebut menjadi batal demi hukum.

Kontrak pembiayaan mudharabah Perbankan Syariah merupakan hubungan hukum perdata antara pihak bank dengan pihak calon nasabah, atau istilah bisnisnya adalah antara kreditur dengan debitur. Sebagai suatu perjanjian, kontrak pembiayaan mudharbah Perbankan Syariah merupakan perjanjian khusus, maka selain mengacu kepada Undang-Undang Nomor 7 Tahun 1992 jo Undang-Undang Nomor 10 Tahun 1998 tentang Perbankan dan Undang-Undang Nomor 21 Tahun 2008 tentang Perbankan Syariah, juga mengacu pada syaratsyarat sahnya perjanjian yang diatur dalam Pasal 1320-1338 KUHPerdata.

Para pihak yang membuat kontrak pembiayaan mudharbah juga mempunyai kebebasan mengatur isi perjanjiannya dengan berdasar pada Pasal 1338 KUHPerdata, yaitu, "Semua perjanjian yang dibuat secara sah berlaku sebagai undang-undang bagi mereka yang membuatnya." Suatu perjanjian tidak dapat ditarik kembali selain dengan kedua belah pihak, atau karena alasanalasan yang oleh undang-undang dinyatakan cukup untuk itu. Suatu perjanjian harus dilaksanakan dengan itikad baik.

Persyaratan umum untuk pembiayaan mudharabah oleh Perbankan Syariah, misalnya Bank Muamalat Cabang Ciamis kepada koperasi adalah sebagai berikut : a) foto copy Anggaran Dasar dan Perubahan dari Koperasi 
yang telah mendapat pengesahan dari Dinas Koperasi setempat; b) foto copy KTP/SIM Pengurus Koperasi; c) Surat Izin Usaha Perdagangan (SIUP); d) Surat Izin Tempat Usaha (SITU); e) Tanda Daftar Perusahaan (TDP); f) Nomor Pokok Wajib Pajak (NPWP); g) Susunan Pengurus Koperasi; h) Hasil Rapat Anggota; i) Laporan Keuangan Tahun Berjalan; i) Rekening Koran 3 (tiga) Bulan terakhir.

Bank Muamalat Cabang Ciamis akan menyediakan dana pembiayaan dalam bentuk uang kepada nasabah/ mudhârib dengan jumlah yang telah disepakati kedua belah pihak, biasanya Bank Muamalat Cabang Ciamis tidak memberikan batasan jumlah pembiayaan, namun untuk nilai minimal dalam pembiayaan mudharabah adalah Rp. 300.000.000,-- (Tiga Ratus Juta Rupiah). Sedangkan untuk jumlah maksimumnya, Bank Muamalat Cabang Ciamis tidak membatasinya, tetapi disesuaikan dengan nilai jaminan yang diberikan oleh nasabah/ mudhârib. Misalkan jaminan muhdârib adalah sertifikat tanah dan bangunan, jika nilai harga dari tanah dan bangunan tersebut adalah Rp. 500.000.000,- (Lima Ratus Juta Rupiah) maka batas maksimal dana yang akan diperoleh nasabah/ mudhârib adalah nilai harga tanah dan bangunan dikali 80 \% (Rp. 500.000.000,- x 80 \% = Rp. 400.000.000,- ) dan hasil tersebut menjadi batas maksimal bagi pembiayaan mudharabah ini.

Sedangkan hasil wawancara dengan Nurida selaku Koordinator Financing di Bank Muamalat Cabang Ciamis karyawan Bank Muamalat Cabang Ciamis bahwa cara agar perjanjian baku yang ada dalam produk simpanan agar tidak menyimpang dari asas kebebasan berkontrak adalah pihak Bank Muamalat Cabang Ciamis menyediakan blanko (formulir, model) perjanjian permohonan pinjaman atau dikenal dengan sebutan mudharabah, bentuk draf perjanjian dan isinya telah disiapkan terlebih dahulu (standard form). Formulir ini disodorkan kepada setiap calon tertanggung. Isi dari standar formulir tersebut tidak diperbincangkan terlebih dahulu dengan pemohon. Kepada pemohon hanya dimintakan pendapatnya apakah dapat menerima syarat-syarat tersebut di dalam formulir itu atau tidak.

Hal tersebut menunjukkan bahwa kontrak pembiayaan mudharbah dalam praktiknya tumbuh sebagai perjanjian standar (standard contract). Namun demikian, pihak Bank Muamalat agar perjanjian mudharabah-nya tidak melanggar asas kebebasan berkontrak, selalu menjelaskan isi dan syarat yang harus dipenuhi oleh pihak calon nasabah. 
Berdasarkan pengamatan dan analisa yang dilakukan, maka terdapat beberapa ketentuan dalam kontrak baku pembiayaan mudharabah yang dibuat oleh Bank Muamalat Cabang Ciamis, yang tidak sesuai dengan hukum, khususnya hukum Islam dan juga Fatwa Dewan Syariah Nasional (DSN) MUI terhadap akad mudharabah yang dilakukan oleh Bank Muamalat Cabang Ciamis dan Nasabah, di antaranya yaitu bahwa Bank Muamalat Cabang Ciamis tidak benar-benar menerapkan akad mudharabah namun hakikatnya menjalankan akad utang piutang dan bukan akad mudharabah dalam hubungannya dengan nasabah.

Jenis produk yang ditawarkan oleh bank syariah secara umum dapat ditelusuri di Pernyataan Standar Akuntansi Keuangan (PSAK) Nomor 59 tentang akuntansi perbankan syariah yang menjelaskan secara global pengakuan dan pengukuran serta penyajian laporan keuangan produk-produk yang ditawarkan bank syariah. PSAK Nomor 102 sampai dengan 107 menjelaskan lagi produkproduk tersebut lebih terperinci yang terdiri dari produk murabahah, salam, isthisna', mudharabah, musyarakah, dan ijarah. Adanya fatwa Dewan Syariah Nasional MUI Nomor 4 sampai dengan 9 semakin mengukuhkan dan menjelaskan prinsip operasional bank syariah dengan produk-produknya tersebut.

Berdasarkan praktik yang terjadi di Bank Muamalat Cabang Ciamis, maka dapat diamati pokok-pokok inti praktik yang terjadi pada Bank Muamalat cabang Ciamis yaitu bank menghimpun dana dari nasabah yang kelebihan dana (shâhibu al-mâl) yang mana saat itu posisi bank adalah sebagai mudhârib. Setelah itu maka pihak bank menyalurkan dana tersebut kepada pihak yang membutuhkan dana, yang mana bank mengaku sebagai shâhibu al-mâl dan pihak yang membutuhkan dana atau koperasi bertindak sebagai mudhârib. Setelah pihak koperasi menerima pinjaman pembiayaan dalam bentuk tunai, maka koperasi bertindak sebagai shâhibu al-mâl untuk anggota koperasi pada akad lain yaitu akad murabahah (Jual Beli). Nisbah bisa ditawar sesuai dengan keinginan mudhârib hingga nantinya akan disepakati bersama. Jangka waktu sudah ada sebelum akad dan dapat berubah setelah jangka 1 tahun tersebut habis, yaitu bisa diperpanjang atau tidak tergantung keputusan bersama. Dan jika terjadi kerugian maka yang menaggung adalah mudhârib. Bertitik tolak kepada informasi di atas dapat disimpulkan bahwa Bank Muamalat Cabang 
Ciamis tidak menjalankan mudharabah murni melainkan mudharabah wa almurabahah. Proses pembiayaan yang terjadi di Bank Muamalat Cabang Ciamis dapat dilihat pada gambar berikut:

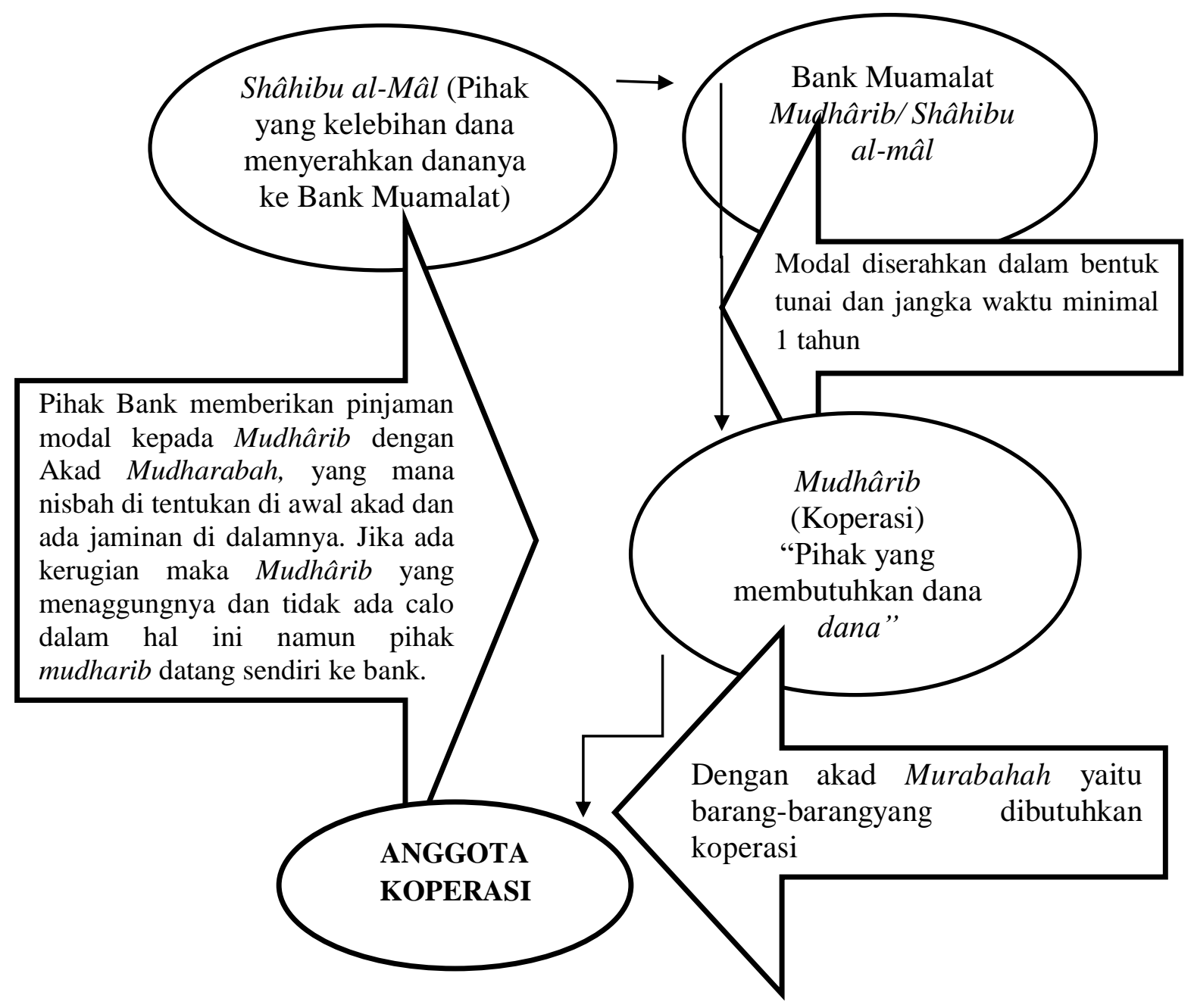

Sumber : Bank Muamalat Cabang Ciamis, yang diolah oleh Penulis

Alur pembiayaan mudharabah yang digunakan Bank Muamalat Cabang Ciamis tidak sesuai dengan ketentuan yang digariskan oleh hukum Islam dan fatwa Dewan Syariah Nasional MUI, ketidak sesuaian itu yaitu :

a. Jangka waktu usaha, tata cara pengembalian dana, dan pembagian keuntungan berdasarkan ketentuan Bank Muamalat Cabang Ciamis. Padahal berdasarkan fatwa Dewan Syariah Nasional MUI bahwa jangka waktu usaha, tata cara pengembalian dana, dan pembagian keuntungan berdasarkan kesepakatan bersama (Bank dan Mudhârib)

b. Ada biaya administrasi $1 \%$ dari total pinjaman, sedangkan berdasarkan fatwa Dewan Syariah Nasional MUI dijelaskan bahwa tidak ada biaya administrasi yang ditentukan dari pinjaman. 
c. Kerugian ditanggung peminjam dana (mudharib), sedangkan berdasarkan fatwa Dewan Syariah Nasional MUI dijelaskan bahwa kerugian ditanggung oleh shâhibu al-mâl (Bank Muamalat).

d. Beban biaya dalam pembuatan akad dibebankan kepada pihak nasabah/ mudhârib semata tidak kepada pihak Bank Muamalat Cabang Ciamis. Seharusnya beban biaya dalam pembuatan akad tidak hanya dibebankan kepada nasabah/ mudhârib tetapi pihak bank pun harus menanggungnya, sebab yang akan mendapat pembagian keuntungan dalam pembiayaan mudharabah tidak hanya untuk nasabah/ mudhârib saja tetapi juga pihak Bank.

Untuk lebih jelasnya, berikut tabel analisis perbandingan antara Pembiayaan Mudharabah Bank Muamalat Cabang Ciamis dengan Fatwa DSN (Dewan Syariah Nasional) Nomor 07/DSN-MUI/IV/2000

\begin{tabular}{|c|l|l|}
\hline No & \multicolumn{1}{|c|}{ Bank Muamalat Ciamis } & \multicolumn{1}{|c|}{ Fatwa DSN MUI } \\
\hline 1. & Bank sebagai shâhibu al-mâl & LKS sebagai shâhibu al-mâl \\
\hline 2. & $\begin{array}{l}\text { Jangka waktu usaha, tata cara } \\
\text { pengembalian dana, dan } \\
\text { pembagian keuntungan } \\
\text { berdasarkan ketentuan Bank }\end{array}$ & $\begin{array}{l}\text { Jangka waktu usaha, tata cara } \\
\text { pengembalian dana, dan } \\
\text { pembagian keuntungan } \\
\text { berdasarkan kesepakatan } \\
\text { bersama }\end{array}$ \\
\hline 3. & $\begin{array}{l}\text { Usaha mudharib adalah simpan } \\
\text { pinjam uang dengan bunga } \\
\text { (Tidak Halal) }\end{array}$ & $\begin{array}{l}\text { Usaha mudharib bebas sesuai } \\
\text { kesepakatan dan halal }\end{array}$ \\
\hline 4 & $\begin{array}{l}\text { Ada biaya administrasi 1\% dari } \\
\text { total pinjaman }\end{array}$ & $\begin{array}{l}\text { Tidak ada biaya administrasi } \\
\text { yang ditentukan dari pinjaman }\end{array}$ \\
\hline 5. & $\begin{array}{l}\text { Jumlah pinjaman jelas dan } \\
\text { dalam bentuk tunai }\end{array}$ & $\begin{array}{l}\text { Jumlah pinjaman jelas dan } \\
\text { dalam bentuk tunai }\end{array}$ \\
\hline 6. & $\begin{array}{l}\text { Kerugian ditanggung peminjam } \\
\text { dana (mudhârib) }\end{array}$ & $\begin{array}{l}\text { Kerugian ditanggung pemilik } \\
\text { dana (shahibu al-mân) }\end{array}$ \\
\hline 7. & Ada jaminan & Ada jaminan \\
\hline 8. & $\begin{array}{l}\text { Biaya operasional dibebankan } \\
\text { kepada mudhârib }\end{array}$ & $\begin{array}{l}\text { Biaya operasional dibebankan } \\
\text { kepada mudhârib }\end{array}$ \\
\hline
\end{tabular}

Berdasarkan hasil analisa tersebut, dapat dijelaskan bahwa proses pembiayaan pada Bank Muamalat Cabang Ciamis tidak sesuai dengan Fatwa DSN (selanjutnya disingkat Dewan Syariah Nasional) Nomor 07/DSNMUI/IV/2000, yang mengatur tentang proses pembiayaan mudharabah. Bahkan 
pada kenyataanya di Bank Muamalat Cabang Ciamis tidak ditemukan adanya akad mudharabah yang halal, di mana seharusnya pihak Koperasi menyalurkan pinjaman modal kepada anggotanya dengan akad murabahah (Jual Beli) sesuai dengan yang di katakan yaitu akad Mudharabah wa al-Murabahah.

Selanjutnya, bila lebih dicermati pada status ganda Bank Muamalat Cabang Ciamis, maka akan didapati bahwa yang dilakukan oleh Bank Muamalat Cabang Ciamis sesungguhnya saat ini merupakan akad utang piutang dan bukan mudharabah, kamuflase pada bentuk akad dan istilah syar'i tidaklah merubah hakikat sebenarnya pada susbtansi akad utang piutang dalam skenario status ganda bank.

Berikut skenario akad utang piutang yang dijalankan oleh Bank Muamalat Cabang Ciamis. Pihak bank yang dalam status pertama sebagai pelaku usaha dan menerima modal dari nasabah pertama (diasumsikan sebagai kreditur) kemudian tidak amanah untuk menjalankan perannya sebagai pelaku usaha sesuai akad mudharabah dimaksud namun Bank Muamalat Cabang Ciamis malah kemudian menyalurkan kembali dana tersebut kepada pihak nasabah lain (diasumsikan sebagai debitur) yang hendak berlaku sebagai pelaku usaha, pada kali ini bank memposisikan diri sebagai pemodal yang pada hakikatnya uang modal yang ada pada bank merupakan uang milik nasabah pada akad mudharabah pertama.

Subtansi dari skenario status ganda Bank Muamalat Cabang Ciamis ini ialah bank berupaya mengalokasikan dana terhimpun dari pihak lain yang dijanjikan akan kembali dananya oleh bank seiring waktu berjalan beserta bagi hasilnya (bunga uang). Hal ini berjalan dari suatu usaha kosong yang pada hakikatnya tidak pernah bank lakukan kecuali hanya menerima dan menyalurkan dana serta mengambil keuntungan atasnya (menyerupai pinjaman bank terhadap uang nasabah pada bank konvensional yang disertai bunga pinjaman). Aliran uang nasabah pertama tadi kemudian dialokasikan oleh bank dalam bentuk penyaluran dana kepada pihak lainnya (Bank Muamalat pada hakikatnya bukan pemilik uang yang sebenarnya), di mana bank kali ini menuntut pengembalian dana seiring waktu berjalan beserta bagi hasilnya (bunga uang) atas modal yang hakikatnya bukan milik bank namun milik nasabah pertama yang berperan sebagai kreditur, dalam kedua proses tadi diisyaratkan adanya 
keuntungan atasnya, sebagaimana diketahui bahwa pengambilan keuntungan dari utang piutang adalah riba.

Adanya ketidakseimbangan kedudukan para pihak dalam suatu perjanjian, sering menyebabkan pihak yang kedudukan lebih rendah akan mengalami keadaan yang kurang menguntungkan. Ketidakseimbangan dalam perjanjian dapat dimanfaatkan oleh pihak yang dominan, yang mengakibatkan pihak bank memiliki potensi untuk melakukan penyalahgunaan keadaan misalnya dalam pembiayaan mudharabah oleh bank syariah khususnya Bank Muamalat Cabang Ciamis, kontrak pembiayaan mudharabah memuat klausula eksonerasi/eksemsi berupa menambah hak dan/ atau mengurangi kewajiban bank, atau mengurangi hak dan/ atau menambah kewajiban nasabah debitur.

Selain memperhatikan asas kebebasan berkontrak, perlu kiranya diperhatikan pula penerapan asas keseimbangan dalam kontrak pembiayaan mudharabah yang dijabarkan dalam perumusan hak dan kewajiban para pihak, sebagai indikator penentu penjabarannya tampak pada posisi seimbang antara hak dan kewajiban masing-masing pihak dalam kontrak pembiayaan mudharabah. Keseimbangan para pihak hanya akan terwujud apabila para pihak berada pada posisi yang sama kuat, namun Bank syariah sebagai pihak yang dominan sedangkan nasabah pelaku usaha kecil sebagai pihak yang lemah keseimbangan sulit terwujud.

Asas keseimbangan menghendaki kedua belah pihak memenuhi dan melaksanakan kontrak perjanjian. Asas keseimbangan merupakan kelanjutan dari asas persamaan, asas persamaan menempatkan para pihak di dalam persamaan derajat. Kreditur mempunyai kekuatan untuk menuntut prestasi dan jika diperlukan dapat menuntut pelunasan prestasi melalui kekayaan debitur, namun kreditur memikul pula beban untuk melaksanakan perjanjian dengan itikad baik. Dapat dilihat di sini bahwa kedudukan kreditur yang kuat diimbangi dengan kewajibannya untuk memperhatikan itikad baik sehingga kedudukan kreditur dan debitur menjadi seimbang.

Terdapat klausula dalam kontrak pembiayaan mudharabah antara bank syariah khsususnya Bank Muamalat Ciamis dengan pelaku usaha kecil dalam praktik yang tidak mencerminkan asas keseimbangan antara lain adalah: ".....Bank Muamalat Cabang Ciamis berhak dan dengan ini diberi kuasa oleh debitur, untuk sewaktu-waktu tanpa persetujuan debitur untuk mendebet 
rekening tabungan/ giro dan atau rekening-rekening lainnya milik debitur yang ada pada bank untuk pembayaran angsuran ...". Isi klausula tersebut menunjukan bahwa bank Muamalat Cabang Ciamis diberi kekuasaan yang luas untuk mendebet rekening milik debitur. Padahal setiap kontrak, khususnya kontrak pembiayaan mudharabah antara bank syariah dengan nasabah wajib menerapkan asas-asas dalam kontrak.

Terkait dengan Surat Edaran Otoritas Jasa Keuangan (selanjutnya disingkat OJK) yakni SE OJK Nomor. 13/SEOJK.07/2014 Tentang Perjanjian Baku, bank wajib menerapkan asas keseimbangan dalam kontrak pembiayaan. Asas keseimbangan adalah asas yang menghendaki kedua belah pihak memenuhi dan melaksanakan perjanjian yang telah disepakati. Kreditur memiliki kekuatan untuk menuntut prestasi dan jika diperlukan dapat menuntut pelunasan prestasi melalui kekayaan debitur, tetapi kreditur juga mempunyai beban untuk melaksanakan perjanjian itu dengan itikad baik.

Di sini dapat terlihat bahwa kedudukan kreditur yang kuat diimbangi dengan kewajibannya untuk memperhatikan itikad baik sehingga kedudukan kreditur dan debitur menjadi seimbang. Kedudukan bank yang dominan di bandingkan dengan kedudukan nasabah pelaku usaha kecil, maka itikad baik sangat diperlukan dalam melaksanakan kontrak pembiayaan mudharabah oleh bank syariah. hal ini bertujuan untuk menghindari hal-hal yang dapat mengarah pada ketidakadilan. Itikad baik sebagaimana Pasal 1338 ayat 3 KUHPerdata, bahwa suatu perjanjian harus didasari itikad baik, artinya pelaksanaan suatu perjanjian itu harus didasarkan pada norma kepatutan atau sesuatu yang dirasakan sesuai dengan yang patut dalam masyarakat.

Dengan demikian OJK sebagai pengatur dan pengawas perbankan seharusnya campur tangan dalam pembuatan kontrak pembiayaan mudharabah, di mana kontrak pembiayaan mudharabah dibuat oleh bank syariah harus diketahui dan disetujui oleh OJK serta menentukan klausula tertentu yang harus dimuat atau dilarang dalam suatu kontrak pembiayaan mudharabah khususnya dengan pelaku usaha kecil.

\section{Kesimpulan}

Kontrak baku yang disandingkan dengan akad mudharabah yang notabenenya adalah akad yang memerlukan musyawarah, akan menyebabkan 
ketidak selarasan dan ketidak adilan. Problematika ini akan berdampak pada kehidupan nasabah, di mana nasabah akan merasa dirugikan atas kontrak yang dibuat secara sepihak (contract standart) tersebut. Oleh sebab itu, pihak Bank Syariah perlu memberitahukan mengenai adanya negosiasi terhadap perjanjian tersebut serta perlu adanya klausul yang menyatakan bahwa kontrak ini telah disesuaikan dengan ketentuan peraturan perundang-undangan termasuk ketentuan peraturan Otoritas Jasa Keuangan".

\section{Daftar Pustaka}

Anshori, Abdul Ghofur, 2010, Hukum Perjanjian Islam Di Indonesia; Konsep, Regulasi Dan Implementasi, Yogyakarta, Gadjah Mada University Press.

Endang, 2010, Perbankan Syariah: Tinjauan dan Beberapa Segi Hukum, Jakarta, Ghalia Indonesia.

Fuady, Munir, 2001, Hukum Kontrak dari Sudut Pandang Hukum Bisnis, Bandung, Citra Aditya Bakti.

Himawan, Ifan, Meiska Veranita, Yuliana Indah Saputri, 2014, Perlindungan Hukum Bagi Nasabah Debitur Bank Sebagai Konsumen Dalam Penggunaan Kontrak Standar Ditinjau Dari Undang-Undang No.8 Tahun1999 Tentang Perlindungan Konsumen, Privat law, Vol. 2.

Ifayah, Luluk, 2008, 'Implementasi Mabda' Hurriyyah At-Ta'Qud dalam Lembaga Keuangan Berbasis Syari'ah (Kajian Analitis Terhadap Kontrak Baku (Standard Contract)," Ulumuddin, Vol. 2.

Khatimah, Husnul, 2009, Analisis Factor-Faktor Yang Mempengaruhi Penyaluran Dana Pebankan Syariah Di Indonesia Sebelum Dan Sesudah Akselerasi Perbankan Syariah 2007/2008, Optimal, Vol.3.

Muhammad, Abdul Kadir, 1993, Hukum Perdata Indonesia Bandung, Aditya Bakti.

Paska, Roni, 2012, Hak-Hak Nasabah Dalam Penerapan Kontrak Baku Pada Akad Mudharabah Di PT. BPRS Margirizki Bahagia Yogyakarta, Yogyakarta, UIN Sunan Kalijaga.

Sjahdeni, Sutan Remy, 1993, Kebebasan Berkontrak dan Perlindungan yang KeseimbanganBagi Para Pihak dalam Perjanjian Kredit Bank Indonesia, Jakarta, Institut Bankir Indonesia. Hukum Perbankan Indonesia, Jakarta, Ghalia Indonesia. 
Subekti, 1996, Hukum Perjanjian, Jakarta, Intermasa.

Subekti dan Tjitrosudibio, 2004, Kitab Undang-Undang Hukum Perdata, Jakarta, Pradnya Paramita.

Zaenudin, 2014, Pengaruh Pendapatan Bagi Hasil Mudharabah, Musyarakah Dan Murabahah Terhadap Bagi Hasil Tabungan (Studi Pada Ksu Bmt Taman Surga Jakarta), Jurnal Etikonomi, Vol. 13.

\section{Perundang-Undangan}

Undang-Undang Nomor 7 Tahun 1992 jo Undang-Undang Nomor 10 Tahun 1998 tentang Perbankan

Undang-Undang Nomor 21 Tahun 2008 tentang Perbankan Syariah 